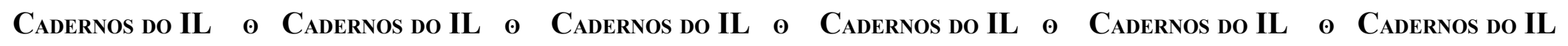

\title{
APRESENTAÇÃO DO NÚMERO 39 DOS CADERNOS DO IL: A ABUNDÂNCIA DOS MELHORES
}

\author{
Há o texto multiplice, que substitui \\ a unicidade de um eu pensante pela multiplicidade \\ de sujeitos, vozes, olhares sobre o mundo. \\ Ítalo Calvino
}

Talvez uma das maiores conquistas da era digital seja a possibilidade de pensar coletivamente sem as aparas das singularidades instituídas. A civilização da era da internet globalizada não obedece às coerções rígidas dos papéis constituídos. Se há áreas e se há especialistas, o certo é que os conteúdos já não são posse isolada. As matérias estão aí para serem discutidas, pensadas, trabalhadas por quem se julgar preparado para tanto. $\mathrm{Na}$ arte literária, a figura do escritor que escreve para o leitor que lê naufraga no oceano da internet, onde quem escreve, lê e quem lê, se quiser, também escreve. Na ciência, a inclusão cada vez mais precoce de jovens no multiverso das questões não respondidas rompe o dogma de que apenas os nobremente diplomados podem produzir conhecimento. Na realidade, parece que a lógica dos territórios divididos passa por uma mudança na qual os sujeitos se incorporam em uma coletividade inteligente de ampla participação. E, nesse novo panorama, um professor que não oriente os estudantes a produzirem textos não é um educador, é um autocentrado detentor de poder. Verdadeiro professor é o que liberta sujeitos e democratiza temas.

É claro que há questões sectárias quanto a essa liberdade toda (aliás, posições contra a liberdade são tão velhas quanto a água). E os argumentos dessas posições têm um apelo facilmente respaldável. De um lado, mora a defesa de que somente estudos avançados podem fazer progredir as áreas do conhecimento; de outro lado, está a certeza de que os jovens não têm conhecimento para tanto. A esse duplo argumento, de mesma face, a do preconceito, há, contudo, uma reposta que parece ser indubitável: as áreas avançam quando novas ideias surgem. É isso que, por sinal, as eterniza e oxigena: o desejo de redirecionar noções e de impertinentemente apontar novas perguntas, as quais não se satisfazem com velhas réplicas. E por essa força, sem as disciplinas da experiência, é que se faz o futuro. De alguma maneira, esse tipo de circunstância aproxima a natureza do conhecimento à instável e múltipla utopia de um Cnossos mitológico. O palácio de Cnossos - diferente das muralhas da Micenas helênica, feitas de blocos enormes, ciclópicos - era um complexo na arquitetura, múltiplo na decoração das salas, engenhoso nos fluxos das redes de águas.

Toda a energia investida em Micenas na massa das muralhas foi impregnada em Cnossos para refinar o modo de vida, para complicar a planta, para fazer proliferar todo um luxo de detalhes arquitetônicos: escadarias, pátios, colunas, estátuas, andares, terraços, antecâmaras, grandes salas de solenidades, pequenas peças secretas, câmaras de tesouro,

Cadernos do IL. Porto Alegre, n. ${ }^{\circ}$ 39, dezembro de 2009. p. 3-4.

http://www.seer.ufrgs.br/cadernosdoil/ 


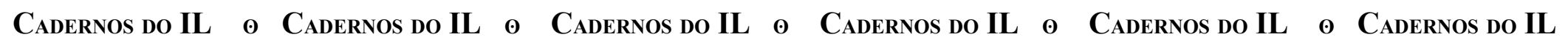

esquinas, baixios, impasses... ${ }^{1} \mathrm{O}$ mundo seguro micênico era o contraponto do espaço aberto de Cnossos, que não divide o interior do exterior, o idêntico do diverso, mas inventa labirintos. Nessa forma de ver coisas de forma múltipla, permitir a ampla publicação é também provocar "a abundância dos melhores".

$\mathrm{Na}$ esteira desta perspectiva poliédrica de Cnossos, este número dos Cadernos IL traz artigos que contemplam diversas perspectivas dos estudos literários. Sobre a poesia brasileira, temos "POÉTICA DO LABOR E DO SABOR DE MANOEL DE BARROS" e "MEMÓRIA, IRONIA E LÚDICO EM "AUTO-RETRATO", DE MANUEL BANDEIRA", abordagens bastante originais de poemas desses dois poetas.

$\mathrm{O}$ romance permanece sendo estudado nas suas mais diferentes realizações, o que pode ser conferido nos ensaios "DO ROMAN AO RÉCIT? METAMORFOSE E ESCRITURA DO DESASTRE EM THOMAS L'OBSCUR, DE MAURICE BLANCHOT", além dos artigos sobre a obra de Erico Verissimo "O TEMPO $\boldsymbol{E} \boldsymbol{O}$ VENTO: ROMANCE HISTÓRICO E ROMANCE POLÍTICO" e "NOTÍCIAS DO CAMPO E DA CIDADE: A FONTE JORNALÍSTICA EM O RETRATO EO ARQUIPÉLAGO". O romance contemporâneo está representado pela obra de Patrícia Melo, através dos estudos "O CONTRAPONTO DO EROTISMO NA LITERATURA DE AUTORIA FEMININA DE LUCI COLLIN E PATRICIA MELO” e "LEGITIMAÇÃO DE CRIMINOSOS EM O MATADOR, DE PATRÍCIA MELO: VERDADES SOBRE PUREZA E CRIME".

Também as reflexões teóricas têm espaço neste número com "LITERATURA: ENTRE A INDIGÊNCIA E A FILOSOFIA", "EXPERIÊNCIA ESTÉTICA E ESTÉTICA DA RECEPÇÃO" e "ESTÉTICA DA RECEPÇÃO E CÂNON", apontando para a necessidade sempre importante de renovar a leitura de nossos referenciais teóricos.

Honrados com a distinção de sermos convidados dos Cadernos do IL como organizadores, abrimos esta edição especial com a certeza de que o leitor terá a abundância dos melhores em estudos sobre literatura, considerando que os artigos trazem a perspectiva de questionamento dos paradigmas de produção do conhecimento e enfatizam a contribuição da literatura para a renovação das formas de compreensão da realidade e como força de resistência à padronização e à hegemonia do pensamento, de modo a iluminar a percepção de problemas relacionados a diversas áreas da esfera social.

Márcia Ivana de Lima e Silva (UFRGS)

Miguel Rettenmeier (UPF)

Organizadores Convidados

${ }^{1}$ LÉVY, Pierre. A inteligência coletiva. 2a ed. São Paulo: Loyola, 2007. p. 210.

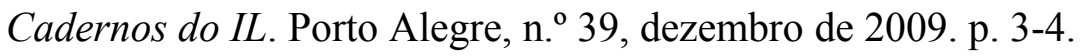

http://www.seer.ufrgs.br/cadernosdoil/ 